\title{
From simple rings to one-dimensional channels with calix[8]arenes, water clusters, and alkali metal ions
}

\author{
Rémi D. Bergougnant, Adeline Y. Robin and Katharina M. Fromm* \\ University of Fribourg, Department of Chemistry, Chemin du Musée 9, CH-1700 Fribourg, Switzerland
}

\begin{abstract}
The macrocycle 4-tert-butylcalix[8]arene (L) was reacted with alkali metal carbonates $\left(\mathrm{Li}_{2} \mathrm{CO}_{3}, \mathrm{Na}_{2} \mathrm{CO}_{3}, \mathrm{~K}_{2} \mathrm{CO}_{3}, \mathrm{Rb}_{2} \mathrm{CO}_{3}\right.$, and $\left.\mathrm{Cs}_{2} \mathrm{CO}_{3}\right)$ at the interface of a biphasic THF/water system. Needle-like crystals with a general formula [A $\mathrm{A}_{x}(4$-tert-butylcalix [8]arene$\left.x \mathrm{H})(\mathrm{THF})_{y}\left(\mathrm{H}_{2} \mathrm{O}\right)_{z}\right]$ (with $\mathrm{A}=\mathrm{Li}, \mathrm{Na}, \mathrm{K}, \mathrm{Rb}, \mathrm{Cs}, x=1,2, y=4,5,8$, and $\left.z=6,7\right)$ were thereby obtained. The solid state structures were investigated by X-ray diffraction of single crystals and by TGA measurements. They do not appear to be maintained in solution.
\end{abstract}

\section{Introduction}

Calix $[n]$ arenes are known for their excellent coordination ${ }^{1}$ and extraction ${ }^{2-4}$ capacities, ${ }^{1-4}$ and have been studied as model systems for the design of catalysts ${ }^{5}$ and sensing receptors. ${ }^{6}$ Weak interactions involving both their $\mathrm{OH}$ groups and aromatic rings can give rise to complicated supramolecular arrangements. ${ }^{7-9}$ In addition to the large choice of ring sizes, calixarenes can adopt different conformations, which can be tuned by substituents at the upper and/or lower rims. In the calixarene family, calix[4]arenes have been the most intensively studied, ${ }^{10}$ while calix[8] arenes remain comparatively little investigated in the solid state. ${ }^{11}$ This is certainly due to different reasons such as limited solubility, poor control over stereoselective substitution reactions at the two rims, and finally the high flexibility of the molecules itself, which allow a large variety of structural conformations and hence hinder long-range order in the solid state. While calix[4]arenes can be observed in four conformations (cone, partial cone, 1,2alternate or 1,3-alternate) in solution, calix[8]arenes can adopt in principle more conformations, although the 'pleated loop' conformation is favored even in solution because of intramolecular hydrogen bonding by the $\mathrm{OH}$ groups. ${ }^{12}$ This hydrogen bond stabilization may be weakened upon metallation of the hydroxide groups, leading to more flexible conformations.

Water molecules are important in both biological and physical systems, and the hydrogen-bonding capacities and high

Keywords: Alkali metal ions; Water aggregates; 4-tert-Butylcalix[8]arene; Channel structures.

* Corresponding author. Tel.: +41 26300 8732; e-mail: katharina.fromm@ unifr.ch

URL: http://www.chem.unifr.ch/kf/index.html dipole moment of the water molecule make water a very special solvent in chemistry. ${ }^{13,14}$ Much theoretical work has been devoted to understand the nature of water aggregates formed in various phases ${ }^{15-18}$ and materials such as 'metal-organic frameworks' (MOFs) and 'nanotubes' have provided numerous examples where such aggregates may be studied in the solid state. ${ }^{19-24}$ Here, we present the evidence that calix[8]arene derivatives may be used to stabilize water aggregates within one-dimensional channels formed by stacking of the calixarenes. These systems have been obtained, in all but one case, by interfacial crystallization.

\section{Results and discussion}

Calixarenes have been frequently used to assist transport through membranes and between biphasic systems. ${ }^{25}$ Here, we have exploited this characteristic for the generation of single crystals of calix [8] arene derivatives. The biphasic system used was composed of (i) a saturated aqueous solution of alkali metal carbonate beneath (ii) a suspension of 4-tertbutylcalix[8]arene (L) in THF. Although water and THF are normally completely miscible, phase separation occurs here due to the saturation of the aqueous solution in carbonate. We presume that calixarene molecules at the interface are oriented with their $\mathrm{OH}$ groups toward the aqueous phase, while the apolar part of the ligand is oriented into the THF phase. Some degree of deprotonation of the calixarene must occur as a result of the basicity of the aqueous phase, so that, through coordination, alkali metal cations can be bound at the interface and even pass into the THF phase. What is in fact observed is that the insoluble calixarene first concentrates at the interface, causing the THF phase to clear, and then deposition of single crystals at the interface occurs as THF preferentially evaporates out. 


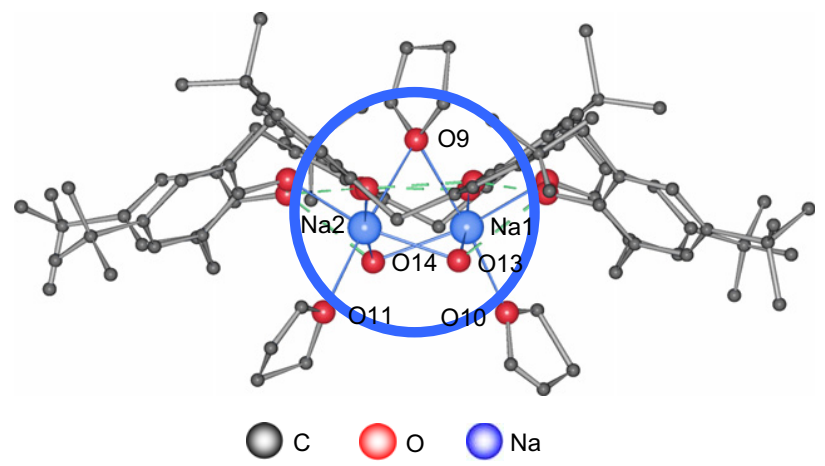

Figure 1. The asymmetric unit of $\mathbf{1}$ ( $\mathrm{H}$ atoms and non-coordinating solvent omitted for clarity).

In preliminary experimentation with $\mathrm{Na}_{2} \mathrm{CO}_{3}$, crystals with the stoichiometry $\left[\mathrm{Na}_{2}(\mathrm{~L}-2 \mathrm{H})(\mathrm{THF})_{4}\left(\mathrm{H}_{2} \mathrm{O}\right)_{5}\right]$, $\mathbf{1}$, were obtained from a homogeneous solution in THF alone. ${ }^{26}$ The structure determination (Fig. 1) showed the two sodium ions to have a nearly octahedral environment, formed by six oxygen atoms. Two water molecules and one THF act as bridging ligands to each sodium ion. Furthermore, two oxygen atoms of the ligand L bind to each cation, one of them being deprotonated, the other not. The eight oxygen atoms of the ligand $\mathrm{L}$ are close to coplanar, the sodium ions being ca. $0.95 \AA$ from the mean plane. A terminal THF molecule completes the coordination sphere of each cation. One disordered THF and two water molecules are also found in the unit cell but are not bound to the metal ions.

A species containing a higher water/THF ratio is obtained with lithium ions, and this may explain its higher degree of aggregation. Here, however, as with all the other alkali metals, the formation of a crystalline complex was the result of using the interfacial crystallization method. Thus, reaction of 4-tert-butylcalix[8] arene with $\mathrm{Li}_{2} \mathrm{CO}_{3}$ yields $\left[\mathrm{Li}_{2}(\mathrm{~L}-2 \mathrm{H})\right.$ $\left.(\mathrm{THF})_{7}\left(\mathrm{H}_{2} \mathrm{O}\right)_{12}\right]_{2}, 2$. Again, each ligand is twice deprotonated, but in contrast to $\mathbf{1}$, the two lithium ions are coordinated by two adjacent rather than two distal oxygen atoms of the calixarene ligand. Each cation has a tetrahedral coordination sphere with three oxygen atoms of the ring and one water molecule. These two bound water molecules $\mathrm{O} 16$ and $\mathrm{O} 18$ are

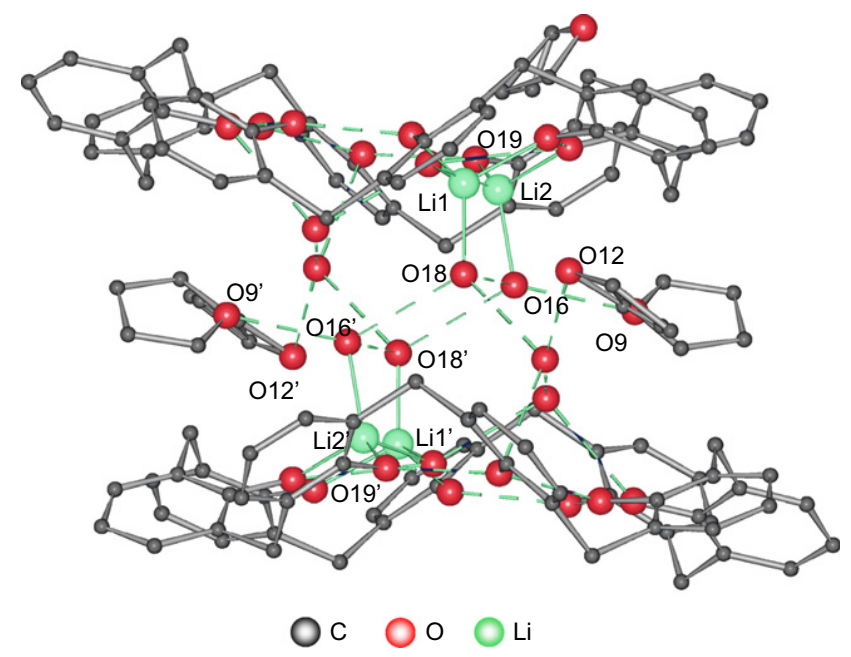

Figure 2. Dimer of $\left[\mathrm{Li}_{2}(\mathrm{~L}-2 \mathrm{H})(\mathrm{THF})_{7}\left(\mathrm{H}_{2} \mathrm{O}\right)_{12}\right]_{2}, 2$ (H atoms, non-coordinating solvent, and tert-butyl groups omitted for clarity). responsible for dimerization via hydrogen bonding to $\mathrm{O}^{\prime} 8^{\prime}$ and $\mathrm{O}_{16}{ }^{\prime}$, respectively (Fig. 2). Comparing $\mathbf{1}$ and 2, it is interesting to note that the lithium ions are further out of the mean plane defined by the oxygen atoms of $\mathrm{LH}_{6}^{2-}$.

In 2, water molecule oxygen atoms $\mathrm{O} 16, \mathrm{O}^{\prime} 6^{\prime}, \mathrm{O} 18$, and $\mathrm{O} 18^{\prime}$ form a square with an average $\mathrm{O}-\mathrm{O}$ distance of 2.833(2) $\AA$ and angle of $86.81(2)^{\circ}$, values similar to those found for such squares in the literature. ${ }^{27}$ Here, the square is stabilized by two hydrogen bond interactions (O16-O9; 2.715(2) А) with two THF molecules, each water molecule in fact being oriented in such a way that one hydrogen atom bridges to the neighboring water molecule whereas the second hydrogen atom points outward from the square. ${ }^{27,28}$ Further water molecules (O17 and symmetry equivalents) are linked to oxygen atoms of the calixarene ligand and are shielded by $\mathrm{H}$ bonding to THF ligands (O12) arranged around the sandwich structure. Other heavily disordered THF and water molecules are found in the structure. Thus, one such disordered THF molecule can be found on the opposite side to the lithium ions of the mean plane of eight oxygen atoms.

An even higher ratio of water/THF is found in the crystalline species isolated with $\mathrm{K}_{2} \mathrm{CO}_{3}$. Thus, single crystals of $\left[\mathrm{K}(\mathrm{L}-\mathrm{H})(\mathrm{THF})_{4}\left(\mathrm{H}_{2} \mathrm{O}\right)_{7}\right], 3$, can be isolated in quasiquantitative yield. This complex has been described previously, ${ }^{29}$ so that only the principal aspects of its structure are described here. The asymmetric unit consists of one singly deprotonated ligand L, one potassium cation, four THF molecules, and seven water molecules. The most important feature of the structure is the fact that a one-dimensional channel structure is now observed, in which the water molecules play a crucial role in the formation of a polymer. The potassium ions are found in a sandwich-type structure, giving dimers, which are bridged, as in $\mathbf{1}$, by water molecules, which are $\mathrm{H}$ bonded to terminal THF ligands. These dimers are linked together by hydrogen bonding to a water cubane cluster on each side (Fig. 3).

The four water molecules $\mathrm{O} 15, \mathrm{O} 16, \mathrm{O} 17$, and $\mathrm{O} 18$ form, together with their symmetry equivalents, a distorted-cubane structure. A 2-fold axis bisects the vectors O18-O18' and O16-O16'. Together with $\mathrm{O} 10$ and its symmetry equivalent, a $\left(\mathrm{H}_{2} \mathrm{O}\right)_{10}$ cluster with $C_{2}$ symmetry is obtained. Even though the hydrogen atoms of the water molecules could not be located in the structure, the $C_{2}$ symmetry of this cluster indicates that 12 out of $16 \mathrm{H}$ atoms in the cubane part of the cluster must connect the eight oxygen atoms to each other, whereas the other four point outward to the coordinated THF ligands. Furthermore, at least one $\mathrm{H}$ atom of $\mathrm{O} 10$ has to point toward O15. Such a structure for $\left(\mathrm{H}_{2} \mathrm{O}\right)_{10}$ has not been described before in the literature, but a similar one has been predicted as one possible, but not the most stable, structure in ab initio studies. ${ }^{28-34}$

Reaction of $\mathrm{Rb}_{2} \mathrm{CO}_{3}$ and $\mathrm{L}$ at the water/THF interface yields single crystals of $\left[\mathrm{Rb}(\mathrm{L}-\mathrm{H})(\mathrm{THF})_{4}\left(\mathrm{H}_{2} \mathrm{O}\right)_{7}\right] 4$ in quasi-quantitative yield. The asymmetric unit of 4 consists of one calix[8] arene, one rubidium ion, one THF molecule linked to the $\mathrm{Rb}$ atoms, and six water molecules, some of which form $\mathrm{H}$ bonds with terminal THF ligands. Free water molecules (O14 and O18) are also present. The hepta-coordination of each $\mathrm{Rb}^{+}$ion involves two interactions with $\mathrm{L},{ }^{35-38}$ 


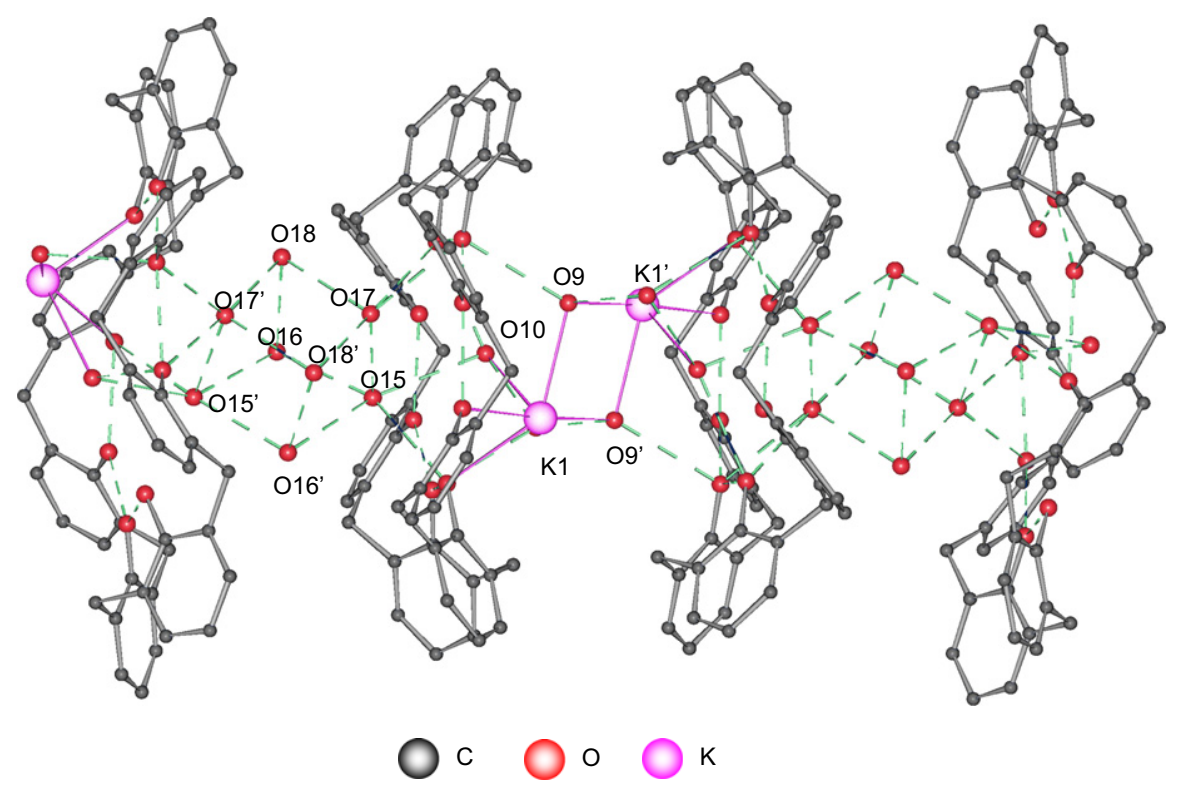

Figure 3. Channel structure of $\left[\mathrm{K}(\mathrm{L}-\mathrm{H})(\mathrm{THF})_{4}\left(\mathrm{H}_{2} \mathrm{O}\right)_{7}\right], 3$ (H atoms, non-coordinating solvents, THF molecules, and tert-butyl groups omitted for clarity).

four interactions with water molecules $\mathrm{O} 16, \mathrm{O}^{\prime} 6^{\prime}, \mathrm{O} 17$, and $\mathrm{O} 17^{\prime}$, which bridge the rubidium ions, and finally one interaction with $\mathrm{O} 9$ (for $\mathrm{Rb} 1$ ) and $\mathrm{O}^{\prime}$ (for $\mathrm{Rb}^{\prime}$ ) from THF molecules (the latter are not shown in Fig. 4). A heterooctahedron of water molecules and rubidium ions is observed, and again a through-ring hydrogen-bonding system leads to a one-dimensional channel in which the rubidium dimer and water clusters are alternately sandwiched between the macrocyclic ligands. In contrast to $\mathbf{3}$, two different water clusters are observed as bridging units between the alkali metal entities. As in $\mathbf{3}$, one of these clusters consists of a distorted cube of eight water molecules $\left(\mathrm{O} 13, \mathrm{O}^{\prime} 3^{\prime}, \mathrm{O} 15, \mathrm{O}^{\prime} 5^{\prime}\right.$, $\left.\mathrm{O} 19, \mathrm{O} 19^{\prime}, \mathrm{O} 20, \mathrm{O} 20^{\prime}\right)$. It is stabilized by two THF molecules (O10 and $\mathrm{O} 11$ at 2.77(3) $\AA$ ). The water molecule, which was stabilizing the cube in $\mathbf{3}$ is, in $\mathbf{4}$, now included in the hetero-octahedron of $\mathrm{Rb}$ ions and water molecules.
The second water aggregate is also a distorted octahedron made of six water molecules (O13", O13"', O15", O15"', O19", O19'") and coordinated by two THF molecules $\left(\mathrm{O} 10^{\prime}, \mathrm{O} 11^{\prime}\right.$ at a distance of 2.77(3) $\AA$ ). This latter cluster is heavily disordered, but could not be fitted to a cubanetype structure.

The mobility of water molecules in $\mathbf{3}$ and $\mathbf{4}$ can be shown by immersion of a crystal of $\mathbf{3}$ and $\mathbf{4}$ into $\mathrm{D}_{2} \mathrm{O}$ for $5 \mathrm{~min}$. The IR spectra of the dried crystals show a strong decrease in the water IR bands around $3380 \mathrm{~cm}^{-1}$ and an increasing signal for $\mathrm{D}_{2} \mathrm{O}$ at $2480 \mathrm{~cm}^{-1}$. The ${ }^{1} \mathrm{H}$ NMR spectrum of 4 shows a dramatic decrease of the proton signals of the $\mathrm{OH}$ groups of $\mathrm{L}$ as well as of the water molecules, an effect also observed for $\mathbf{3}$. The TGA of $\mathbf{4}$ shows the loss of lattice solvent (water and THF) near $40^{\circ} \mathrm{C}$, whereas coordinated THF

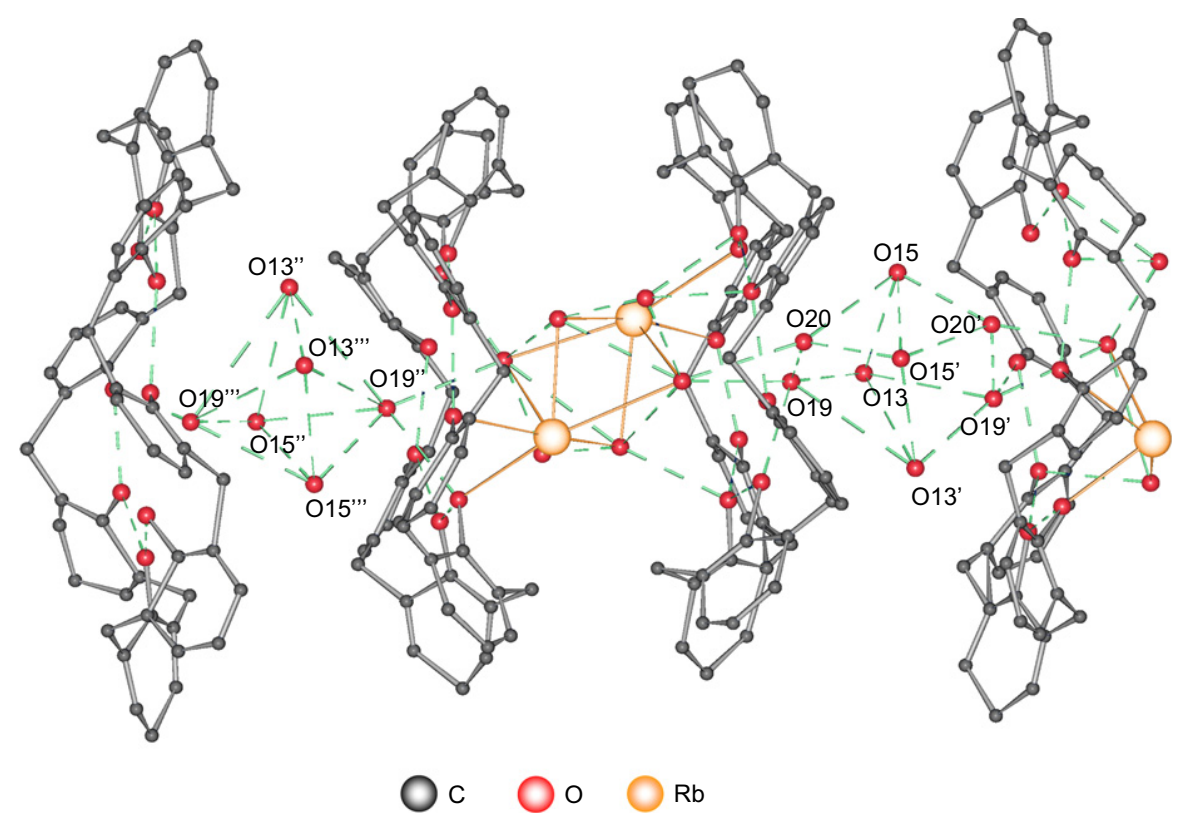

Figure 4. Alternating distorted octahedron and distorted cube of water molecules in $\left[\mathrm{Rb}(\mathrm{L}-\mathrm{H})(\mathrm{THF})_{4}\left(\mathrm{H}_{2} \mathrm{O}\right)_{7}\right], \mathbf{4}(\mathrm{H}$ atoms, non-coordinating solvents, THF molecules, and tert-butyl groups omitted for clarity). 


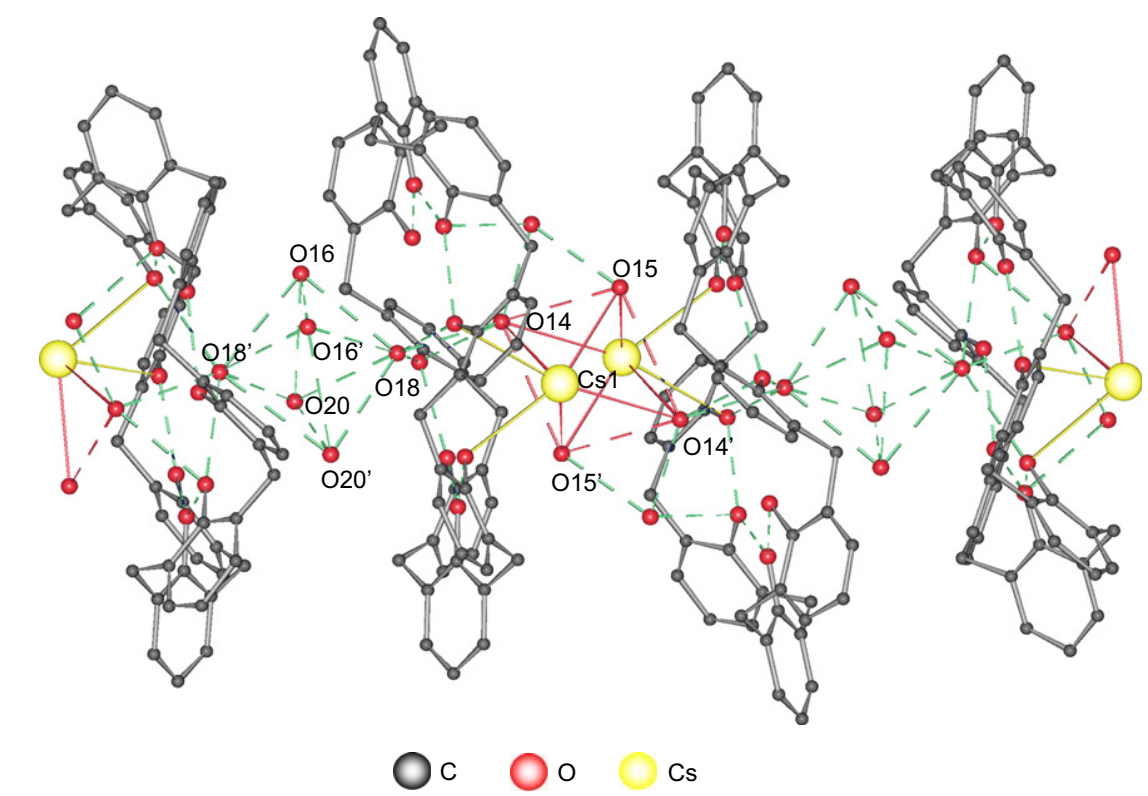

Figure 5. Alternating octahedra of water molecules and hetero-octahedra in $\left[\mathrm{Cs}(\mathrm{L}-\mathrm{H})(\mathrm{THF})_{5}\left(\mathrm{H}_{2} \mathrm{O}\right)_{6}\right], \mathbf{5}$ ( $\mathrm{H}$ atoms, non-coordinating solvents, THF molecules, and tert-butyl groups omitted for clarity).

molecules are lost between 40 and $60^{\circ} \mathrm{C}$. On further heating, water is lost quantitatively between 60 and $140{ }^{\circ} \mathrm{C}$, corresponding to a loss of $7 \%$ in weight, followed by decomposition upon further heating.

Reaction of $\mathrm{Cs}_{2} \mathrm{CO}_{3}$ with 4-tert-butylcalix[8]arene at the water/THF interface yielded single crystals of $[\mathrm{Cs}(\mathrm{L}-\mathrm{H})$ $\left.(\mathrm{THF})_{5}\left(\mathrm{H}_{2} \mathrm{O}\right)_{6}\right], \mathbf{5}$, in quasi-quantitative yield. The asymmetric unit of $\mathbf{5}$ consists of one singly deprotonated ligand $\mathrm{L}$, one caesium ion Cs1, five THF, and six water molecules (Fig. 5). The hepta-coordination of Cs 1 results from two interactions with L-H (Cs1-O3 3.06(1) $\AA$ and Cs1-O2 3.29(1) $\AA$; the bond lengths being as expected from the literature ${ }^{39}$ ), four water molecules, which bridge also to the symmetry equivalent $\mathrm{Cs} 1^{\prime}$ to form a distorted octahedron (as in 4), and finally an oxygen $\mathrm{O} 9$ from a THF molecule. There are also a water molecule O17, which interacts with $\mathrm{O} 14, \mathrm{O} 15$, and a THF molecule, as well as a non-coordinating THF molecule. On the side of $\mathrm{L}$ remote from the cesium ions, three water molecules $(\mathrm{O} 18, \mathrm{O} 16, \mathrm{O} 20)$ and their symmetry equivalents $\left(\mathrm{O}_{1}^{\prime}, \mathrm{O}^{\prime} 6^{\prime}, \mathrm{O} 20^{\prime}\right)$ form a distorted octahedron. O16, O20 and $\mathrm{O} 16^{\prime}, \mathrm{O}_{20}^{\prime}$ are bound to THF molecules $\mathrm{O} 12, \mathrm{O} 10$ and $\mathrm{O} 12^{\prime}, \mathrm{O} 10^{\prime}$. The average distance between water molecules is $3.23 \AA$.

This is the third structure to feature the channels of $\mathrm{L}$, which organize themselves around alkali metal ions and water clusters, here a $\left(\mathrm{H}_{2} \mathrm{O}\right)_{6}$ cluster. TGA of 5 was possible and showed the loss of the five THF molecules per unit in two steps, four in a gradual step between 45 and $75{ }^{\circ} \mathrm{C}$, and the last between 80 and $100{ }^{\circ} \mathrm{C}$ along with the most easily lost water molecules. The latter THF molecule is suggested to be the one linked directly to the caesium cation, as this bond is expected to be stronger than the THF-water interactions. On further heating from 110 to $180{ }^{\circ} \mathrm{C}$, all the remaining water is lost.

The five structures presently determined cover a range from monomeric to polymeric solid state species, with both the charge on the calixarene and the form of solvation varying significantly. As the number of THF molecules diminishes with respect to the number of water molecules, THF becomes increasingly involved in $\mathrm{H}$ bonding rather than coordination, thus completing an 'organic' shell around the polar channel system. The latter is formed by the $\mathrm{OH}-$ and the $\mathrm{O}^{-}$groups of the calixarene ligand, the cations, and the water molecules. All three are found inside the channel systems of $\mathbf{3}, \mathbf{4}$, and $\mathbf{5}$, indicating that the higher concentration of water drives the channel formation. The three channel structures contain water clusters of different sizes, the smallest cation being accompanied by the largest cluster and vice versa. The most important bond lengths of compounds 1-5 are highlighted in Table 1.

For the channel structures, it is interesting to study the ion and water mobility within the crystals. Thus, IR studies during $\mathrm{D}_{2} \mathrm{O}$ exchange were carried out and showed that the inside of the channel, water molecules, and thus probably also the cations, seem to be extremely mobile. In addition to this, in some of the structures, disorder of water molecules is observed at room temperature, while cooling to lower temperatures, i.e. $-40{ }^{\circ} \mathrm{C}$, leads to cracking of the single crystals. This may explain why the quality of the single crystal structures is poor for most of our compounds. Rotational disorder of the tert-butyl groups was apparent in all compounds and all the structures have $R$ values larger than 0.10 . Nonetheless, the essential features of the lattices are well defined and the structures provided useful illustrations of how calix[8]arenes can be used as scaffolds for the construction

Table 1. Ranges of bond lengths in 1-5

\begin{tabular}{lccc}
\hline Compound & $\mathrm{M}-\mathrm{O}(\mathrm{L}) / \AA$ & $\mathrm{M}-\mathrm{O}($ other $) / \AA$ & $\mathrm{O}-\mathrm{O}(\mathrm{H}$ bonds $) / \AA$ \\
\hline $\mathbf{1}$ & $2.326(6)-2.363(6)$ & $2.360(5)-2.669(7)$ & $2.485(7)-2.644(7)$ \\
$\mathbf{2}$ & $1.93(2)-1.97(2)$ & $1.88(3)-2.09(1)$ & $2.431(7)-3.28(2)$ \\
$\mathbf{3}$ & $2.694(7)-2.894(7)$ & $2.739(8)-2.99(1)$ & $2.47(1)-3.33(1)$ \\
$\mathbf{4}$ & $2.83(2)-3.07(2)$ & $2.86(2)-3.31(2)$ & $2.73(3)-3.49(3)$ \\
$\mathbf{5}$ & $3.06(1)-3.29(1)$ & $3.06(1)-3.41(2)$ & $2.42(1)-3.47(2)$ \\
\hline
\end{tabular}


of channel systems. Understanding ion and solvent molecule movement in channels is clearly of relevance to biology and, with this objective, extended studies of these calixarene systems are in progress.

\section{Conclusions}

Interfacial crystallization of alkali metal derivatives of 4-tert-butylcalix[8]arene has provided solids which, in the cases of $\mathrm{K}, \mathrm{Rb}$ and $\mathrm{Cs}$, can be considered to contain channel-like structures in which water clusters separate solvated complex ion units containing the calixarene in a relatively flat conformation essentially defining the channel cross-section. In these particular cases also, THF molecules form a sheath about the polar channel contents, completing thus the apolar shell of the channel formed by the calix[8]arenes.

\section{Experimental}

\subsection{General}

Of all the compounds, only $\mathbf{3}$ gave satisfactory elemental analysis. This is probably due to ready loss of solvent in most cases. All crystallizations were carried out using the interface method, except in the case of the sodium complex, $\mathbf{1}$. IR spectra were collected on a Shimadzu FTIR-8400S instrument equipped with a Golden Gate ATR (attenuated total reflection) system. ${ }^{1} \mathrm{H}$ NMR analysis was performed on a Bruker Advance Spectrometer $250 \mathrm{MHz}$, at $298 \mathrm{~K} .{ }^{13} \mathrm{C}$ NMR analysis was performed on a Bruker Advance Spectrometer $500 \mathrm{MHz}$, at $298 \mathrm{~K}$.

\section{2. $\left[\mathrm{Na}_{2}(\mathrm{~L}-2 \mathrm{H})(\mathrm{THF})_{4}\left(\mathrm{H}_{2} \mathrm{O}\right)_{5}\right] 1$}

Synthesis of 1. 4-tert-Butylcalix[8]arene $\quad(0.1975 \mathrm{~g}$, $0.152 \mathrm{mmol})$ and sodium $(0.5 \mathrm{~g}, 0.02 \mathrm{~mol})$ were introduced in a Schlenk flask under $\mathrm{N}_{2}$ atmosphere. Dried THF $(15 \mathrm{~mL})$ was then added by cryodistillation. This suspension was stirred until total solubilization (45 min). The yellow solution was then concentrated to $5 \mathrm{~mL}$. Toluene ( $1 \mathrm{~mL}$ ) was layered upon the solution for a slow diffusion. After one day the solution was concentrated one more time. After few days, colorless crystals were obtained.

${ }^{1} \mathrm{H} \mathrm{NMR}\left(\mathrm{CDCl}_{3}, 250 \mathrm{MHz}\right): 7.16(\mathrm{~s}, 16 \mathrm{H}, \mathrm{ArCH}), 3.76(8 \mathrm{H}$, $\left.\mathrm{CH}_{2}\right), 3.75$ (s, 16H, THF), $3.71\left(8 \mathrm{H}, \mathrm{CH}_{2}\right), 1.87(\mathrm{~s}, 16 \mathrm{H}$, THF), $1.43\left(\mathrm{~s}, \mathrm{H}_{2} \mathrm{O}\right), 1.29\left(\mathrm{~s}, 54 \mathrm{H}, \mathrm{CH}_{3}\right)$. IR $\left(\mathrm{cm}^{-1}\right)$ : 341.84 (w), 2952.81 (m), 2864.09 (w), 1770.53 (w), 1660.60 (w), 1566.09 (w), 1436.87 (s), 1359.72 (w), $1292.22(\mathrm{~m}), 1201.57$ (w), 1120.56 (w), 1049.20 (w), 879.48 (w), 815.83 (w), $790.76(w), 752.19$ (s).

\section{3. $\left[\mathrm{Li}_{2}(\mathrm{~L}-2 \mathrm{H})(\mathrm{THF})_{7}\left(\mathrm{H}_{2} \mathrm{O}\right)_{12}\right] 2$}

Synthesis of 2 . In a beaker, $10 \mathrm{~mL}$ of THF was slowly layered on top of $20 \mathrm{~mL}$ of an aqueous solution saturated in lithium carbonate. A $20 \mathrm{mg}$ portion $(0.015 \mathrm{mmol})$ of 4-tert-butylcalix[8]arene was added onto the liquid. The solid calixarene slowly accumulated at the THF-water interface. After evaporation (1-2 days) of the solution through Parafilm ${ }^{\mathrm{TM}}$ cover at a temperature of $23{ }^{\circ} \mathrm{C}$, needle-like, colorless crystals grew in quantitative yield.

${ }^{1} \mathrm{H} \mathrm{NMR}\left(\mathrm{CDCl}_{3}, 250 \mathrm{MHz}\right): 7.06(\mathrm{~s}, 16 \mathrm{H}, \mathrm{ArCH}), 3.76(8 \mathrm{H}$, $\left.\mathrm{CH}_{2}\right), 3.74$ (s, 16H, THF), $3.71\left(8 \mathrm{H}, \mathrm{CH}_{2}\right), 1.85(\mathrm{~s}, 16 \mathrm{H}$, THF), $1.43\left(\mathrm{~s}, \mathrm{H}_{2} \mathrm{O}\right), 1.22\left(\mathrm{~s}, 54 \mathrm{H}, \mathrm{CH}_{3}\right) . \operatorname{IR}\left(\mathrm{cm}^{-1}\right)$ : $3305.76(\mathrm{w}), 2954.74$ (s), $2866.02(\mathrm{~m}), 1477.37$ (s), $1361.65(\mathrm{~m}), 1299.93(\mathrm{~m}), 1184.21(\mathrm{w}), 1114.78(\mathrm{w})$, $1049.20(\mathrm{w}), 871.76(\mathrm{~m}), 817.76(\mathrm{w}), 790.76(\mathrm{w}), 702.04$ $(\mathrm{w}), 651.89(\mathrm{w}), 594.03(\mathrm{w}), 574.75(\mathrm{~m}), 551.60(\mathrm{~m})$, 524.60 (s).

\section{4. $\left[\mathrm{K}(\mathrm{L}-\mathrm{H})(\mathrm{THF})_{4}\left(\mathrm{H}_{2} \mathrm{O}\right)_{7}\right] 3$}

Synthesis of 3. In a Petri dish, $10 \mathrm{~mL}$ of THF was slowly layered on top of $20 \mathrm{~mL}$ of an aqueous solution saturated in potassium carbonate. A $50 \mathrm{mg}$ portion $(0.038 \mathrm{mmol})$ of 4-tert-butylcalix[8]arene was added onto the liquid. The solid calixarene slowly accumulated at the THF-water interface. On slow evaporation (1-2 days) of the solution, needlelike, colorless crystals grew in quantitative yield.

${ }^{1} \mathrm{H} \mathrm{NMR}\left(\mathrm{CDCl}_{3}, 250 \mathrm{MHz}\right): 9.63(\mathrm{~s}, 7 \mathrm{H}, \mathrm{OH}), 7.18$ (s, 16H, ArCH), 4.33 (d, 8H, CH $), 3.75$ (m, 16H, THF), 3.47 (d, 8H, $\left.\mathrm{CH}_{2}\right), 1.85$ (m, 16H, THF), $1.58\left(\mathrm{~s}, \mathrm{H}_{2} \mathrm{O}\right), 1.25\left(\mathrm{~s}, 72 \mathrm{H}, \mathrm{CH}_{3}\right)$. ${ }^{13} \mathrm{C}$ NMR $\left(\mathrm{CDCl}_{3}, 500 \mathrm{MHz}\right): 157.03$ (s, 8C, $\left.\mathrm{ArC}(\mathrm{OH})\right)$, $146.18\left(\mathrm{~s}, 16 \mathrm{C}, \operatorname{ArC}\left(\mathrm{CH}_{2}\right)\right), 130.53(\mathrm{~s}, 16 \mathrm{C}, \mathrm{ArCH}), 39.20$ (s, 16C, $\left.\mathrm{ArCH}_{2}\right), 38.60$ (s, 8C, $\left.\mathrm{C}\left(\mathrm{CH}_{3}\right)\right), 37.02$ (s, 24C, $\left.\mathrm{CH}_{3}\right)$. IR $\left(\mathrm{cm}^{-1}\right): 3380.02$ (s), 3245.49 (s), 3150.50 (s), $2901.70(\mathrm{~m}), 2865.54(\mathrm{sh}), 1643.24(\mathrm{~s}), 1473.51$ (s), 1388.65 (m), 1365.51 (m), 1288.36 (w), 1249.79 (s), 1203.50 (s), 1157.21 (vw), 1118.64 (vw), 1056.92 (w), 871.76 (w), 817.76 (w), 786.90 (w), 732.90 (w), 694.33 (m). Anal. Found (calcd): C, 70.71\% (71.3); H, 9.22\% (9.03); O, $17.72 \%$ (17.37).

\section{5. $\left[\mathrm{Rb}(\mathrm{L}-\mathrm{H})(\mathrm{THF})_{4}\left(\mathrm{H}_{2} \mathrm{O}\right)_{7}\right] 4$}

Synthesis of 4 . In a beaker, $10 \mathrm{~mL}$ of THF was slowly layered on top of $20 \mathrm{~mL}$ of an aqueous solution of $0.25 \mathrm{M}$ rubidium carbonate. A $20 \mathrm{mg}$ portion $(0.015 \mathrm{mmol})$ of 4-tert-butylcalix[8]arene was added onto the liquid. The solid calixarene slowly accumulated at the THF-water interface. On slow evaporation (1-2 days) of the solution at a temperature of $23^{\circ} \mathrm{C}$, needle-like, colorless crystals grew in quantitative yield.

${ }^{1} \mathrm{H} \mathrm{NMR}\left(\mathrm{CDCl}_{3}, 250 \mathrm{MHz}\right): 9.63(\mathrm{~s}, 7 \mathrm{H}, \mathrm{OH}), 7.18$ (s, 16H, $\mathrm{ArCH}), 4.34$ (d, 8H, $\left.\mathrm{CH}_{2}\right), 3.75$ (m, 16H, THF), 3.74 (d, 8H, $\left.\mathrm{CH}_{2}\right), 1.85$ (m, 16H, THF), $1.43\left(\mathrm{~s}, \mathrm{H}_{2} \mathrm{O}\right), 1.25(\mathrm{~s}, 72 \mathrm{H}$, $\left.\mathrm{CH}_{3}\right)$. IR $\left(\mathrm{cm}^{-1}\right)$ : $3409.91(\mathrm{w}), 2954.74(\mathrm{~m}), 2862.17(\mathrm{~m})$, 1712.67 (w), 1643.24 (w), 1612.38 (w), 1581.52 (w), 1542.95 (w), 1473.51 (s), 1357.79 (w), 1288.36 (s), 1249.79 (s), 1203.50 (s), $1110.92(\mathrm{w}), 1056.92(\mathrm{~m}), 871.76$ (m), $817.76(\mathrm{w}), 786.90(\mathrm{w}), 732.90(\mathrm{w}), 686.61(\mathrm{w})$, $586.32(\mathrm{w}), 570.89(\mathrm{w})$.

\section{6. $\left[\mathrm{Cs}(\mathrm{L}-2 \mathrm{H})(\mathrm{THF})_{5}\left(\mathrm{H}_{2} \mathrm{O}\right)_{6}\right] 5$}

Synthesis of 5 . In a beaker, $10 \mathrm{~mL}$ of THF was slowly layered on top of $20 \mathrm{~mL}$ of an aqueous solution of $0.20 \mathrm{M}$ caesium carbonate. A $20 \mathrm{mg}$ portion $(0.015 \mathrm{mmol})$ of 4-tert-butylcalix[8] arene was added onto the liquid. The solid calixarene slowly accumulated at the THF-water interface. On slow 
evaporation (1-2 days) of the solution at a temperature of $23{ }^{\circ} \mathrm{C}$, needle-like, colorless crystals grew in quantitative yield.

${ }^{1} \mathrm{H} \mathrm{NMR}\left(\mathrm{CDCl}_{3}, 250 \mathrm{MHz}\right): 9.63(\mathrm{~s}, 7 \mathrm{H}, \mathrm{OH}), 7.17$ (s, 16H, $\mathrm{ArCH}), 4.33$ (d, 8H, $\left.\mathrm{CH}_{2}\right), 3.75$ (m, 16H, THF), $3.52(\mathrm{~d}, 8 \mathrm{H}$, $\mathrm{CH}_{2}$ ), 1.85 (m, 16H, THF), $1.58\left(\mathrm{sh}, \mathrm{H}_{2} \mathrm{O}\right), 1.25(\mathrm{~s}, 72 \mathrm{H}$, $\mathrm{CH}_{3}$ ). IR ( $\left.\mathrm{cm}^{-1}\right): 3589.28(\mathrm{w}), 3365.55(\mathrm{~m}), 3161.11(\mathrm{~m})$, 2952.81 (s), $2906.53(\mathrm{~m}), 2866.02(\mathrm{~m}), 1633.59(\mathrm{~m})$, 1479.30 (s), 1390.58 (w), 1359.72 (m), 1290.29 (m), $1247.86(\mathrm{~m}), 1201.57$ (s), 1155.28 (w), $1118.64(\mathrm{w})$, $1054.99(\mathrm{~m}), 910.34(\mathrm{w}), 871.76(\mathrm{~m}), 817.76(\mathrm{~m}), 784.97$ (w), 661.54 (s), $621.04(\mathrm{~s})$.

\subsection{Single crystal structures}

Diffraction patterns for crystals 1, 2, 4, and 5 were measured on a STOE IPDS diffractometer with monochromated graphite Mo $\mathrm{K} \alpha$ radiation, $\lambda=0.71073 \AA$, generated by a rotating anode Enraf FR590, equipped with an Oxford Cryosystems open flow cryostat, ${ }^{40}$ with an absorption correction by analytical integration. ${ }^{41}$ The structures were solved with direct methods and refined by full-matrix least-squares on $F^{2}$ with the SHELX-99 package. ${ }^{42}$ All heavy atoms were refined anisotropically. However, major disorder in free solvent molecules and some of the tert-butyl groups of the ligand led to rather high $R$ values for all structures. The crystals were measured at $-40{ }^{\circ} \mathrm{C}$, lower temperatures leading to cracking of the single crystals. Crystallographic data for the structures $\mathbf{1}, \mathbf{2}, \mathbf{4}$, and $\mathbf{5}$ reported here have been deposited with the Cambridge Crystallographic Data Center under numbers CCDC-653530, CCDC-652846, CCDC-652847, and CCDC-652848. Copies of the data can be obtained free of charge on application to CCDC, 12 Union Road, Cambridge CB21EZ, UK (fax: (+44)1223-336-033; e-mail: deposit@ccdc.cam.ac.uk).

Single crystal data for $1 . \mathrm{C}_{104} \mathrm{H}_{176} \mathrm{Na}_{2} \mathrm{O}_{17}, M=1744.63$ $\mathrm{g} \mathrm{mol}^{-1}$, monoclinic, space group $P 22_{1} / c$ (No. 14), $a=22.668(4), b=25.508(7), c=23.938(4) \AA, \beta=113.57(2)^{\circ}$, $V=12686.4 \AA^{3}, \quad Z=4, \quad T=240(2) \mathrm{K}, \quad \mu($ Mo $\quad \mathrm{K} \alpha)=$ $0.806 \mathrm{~mm}^{-1}, 21,561$ reflections, 1142 parameters refined, $R 1=\Sigma|| F_{\mathrm{o}}|-| F_{\mathrm{c}}|| / \Sigma\left|F_{\mathrm{o}}\right|=0.1337, \quad w R 2=\left\{\Sigma\left[w\left(F_{\mathrm{o}}^{2}-F_{\mathrm{c}}^{2}\right)^{2}\right] /\right.$ $\left.\Sigma\left[w\left(F_{\mathrm{o}}^{2}\right)^{2}\right]\right\}^{1 / 2}=0.3426$ for $I>2 \sigma$ and $R 1=0.2945, w R 2=$ 0.4153 for all data.

Single crystal data for 2 . Single crystals of $\mathbf{2}$ decayed after $43.5 \%$ completeness of data collection; $\mathrm{C}_{116} \mathrm{H}_{220} \mathrm{Li}_{2} \mathrm{O}_{27}$, $M=2060.86 \mathrm{~g} \mathrm{~mol}^{-1}$, monoclinic, space group $P 2_{1} / c$ (No. 14), $\quad a=20.413(4), \quad b=32.402(7), \quad c=21.638(4) \AA, \quad \beta=$ $114.84(3)^{\circ}, V=12987(5) \AA^{3}, Z=4, T=240(2) \mathrm{K}, \mu($ Mo K $\alpha)=$ $0.993 \mathrm{~mm}^{-1}, 12,222$ reflections, 1306 parameters refined, $R 1=0.1442, \quad w R 2=0.2865$ for $I>2 \sigma$ and $R 1=0.2438$, $w R 2=0.3279$ for all data.

Single crystal data for 4 . Crystal decay observed after $81.7 \%$ data collection; $\mathrm{C}_{104} \mathrm{H}_{157} \mathrm{RbO}_{19}, \quad M=3721.64 \mathrm{~g} \mathrm{~mol}^{-1}$, monoclinic, space group $C 2 / c, a=35.745(7), b=22.459(5)$, $c=28.450(6) \AA, \quad \beta=109.53(3)^{\circ}, \quad V=21525(7) \AA^{3}, \quad Z=4$, $T=243(2) \mathrm{K}, \mu($ Mo K $\alpha)=1.031 \mathrm{~mm}^{-1}, 18,188$ reflections, 8021 observed and 1130 parameters refined, $R 1=0.1380$, $w R 2=0.2866$ for $I>2 \sigma$ and $R 1=0.2742, w R 2=0.3434$ for all data.
Single crystal data for $5 . \mathrm{C}_{108} \mathrm{H}_{163} \mathrm{CsO}_{19}, M=1898.35 \mathrm{~g} \mathrm{~mol}^{-1}$, monoclinic, space group $C 2 / c, a=35.968(7), b=22.437(5)$, $c=28.549(6) \AA, \quad \beta=109.72(3)^{\circ}, \quad V=21688(8) \AA^{3}, \quad Z=8$, $T=240(2) \mathrm{K}, \mu($ Mo $\mathrm{K} \alpha)=1.139 \mathrm{~mm}^{-1}, 48,218$ reflections, 1140 parameters refined, $R 1=0.1893, w R 2=0.4194$ for $I>2 \sigma$ and $R 1=0.2498, w R 2=0.4525$ for all data.

\section{Acknowledgements}

The Swiss National Science Foundation SNF is thanked for most generous support in form of a research professorship to K.M.F. The authors also thank Prof. J. Harrowfield for helpful discussion.

\section{References and notes}

1. Calixarenes 2001; Asfari, Z., Böhmer, V., Harrowfield, J. M., Vicens, J., Eds.; Kluwer Academic: Dordrecht, 2001.

2. Calixarenes for Separations; Lumetta, G. J., Rogers, R. D., Gopalan, A., Eds.; ACS Symposium Series; ACS: Washington, DC, 2000; Vol. 757.

3. Sansone, F.; Fontanella, M.; Casnati, A.; Ungaro, R.; Böhmer, V.; Saadioui, M.; Liger, K.; Dozol, J. F. Tetrahedron 2006, 62, 6749-6753; Lee, J.-W.; Park, S. Y.; Cho, B. K.; Kim, J. S. Tetrahedron Lett. 2007, 48, 2541-2546.

4. Arnaud-Neu, F.; Browne, J. K.; Byrne, D.; Mars, D. J.; McKervey, M. A.; O'Hagan, P.; Schwing-Weill, M.-J.; Walker, A. Chem.-Eur. J. 1999, 5, 175-186.

5. Gutsche, C. D. Calixarenes Revisited: Monographs in Supramolecular Chemistry; Stoddart, J. F., Ed.; The Royal Society of Chemistry: Cambridge, 1998.

6. Beer, P. D.; Cadman, J. Coord. Chem. Rev. 2000, 205, 131-155; Beer, P. D.; Hayes, E. J. Coord. Chem. Rev. 2003, 240, 167189.

7. Atwood, J. L.; Barbour, L. J.; Hardie, M. J.; Raston, C. L. Coord. Chem. Rev. 2001, 222, 3-32.

8. Smith, C. B.; Barbour, L. J.; Makha, M.; Raston, C. L.; Sobolev, A. N. Chem. Commun. 2006, 950-952.

9. Matthews, S. E.; Schmitt, P.; Felix, V.; Drew, M. G. B.; Beer, P. D. J. Am. Chem. Soc. 2002, 124, 1341-1353.

10. Vazquez-Campos, S.; Crego-Calama, M.; Reinhoudt, D. N.; David, N. Supramol. Chem. 2007, 19, 95-106; Baklouti, L.; Harrowfield, J.; Pulpoka, B.; Vicens, J. Mini-Rev. Org. Chem. 2006, 3, 355-384; Sliwa, W. J. Incl. Phenom. Macrocycl. Chem. 2005, 52, 13-37; Harvey, P. D. J. Inorg. Organomet. Polym. 2004, 14, 211-226; Martz, J.; Graf, E.; De Cian, A.; Hosseini, M. W. Perspect. Supramol. Chem. 2003, 7, 177209; Casnati, A.; Sansone, F.; Ungaro, R. Acc. Chem. Res. 2003, 36, 246-254; Hanna, T. A.; Liu, L.; Angeles-Boza, A. M.; Kou, X.; Gutsche, C. D.; Ejsmont, K.; Watson, W. H.; Zakharov, L. N.; Incarvito, C. D.; Rheingold, A. L. J. Am. Chem. Soc. 2003, 125, 6228-6238; Gueneau, E. D.; Fromm, K. M.; Goesmann, H. Chem.-Eur. J. 2003, 9, 509-514.

11. Perret, F.; Suwinska, K.; Bertino, G. B.; Parrot-Lopez, H.; Coleman, A. W. New J. Chem. 2007, 31, 893-900; MartinezAlanis, P. R.; Castillo, I. Tetrahedron Lett. 2005, 46, 8845- 
8848; Schatz, J.; Schildbach, F.; Lentz, A.; Rastatter, S.; Debaerdemaeker, T. Z. Kristallogr. 2001, 216, 182-186; Leverd, P. C.; Huc, V.; Palacin, S.; Nierlich, M. Z. Kristallogr. New Cryst. Struct. 2000, 215, 549-552; Puntus, L. N.; Chauvin, A.-S.; Varbanov, S.; Bunzli, J.-C. Eur. J. Inorg. Chem. 2007, 2315-2326.

12. Gutsche, C. D. Calixarenes; The Royal Society of Chemistry: Cambridge, UK, 1989.

13. Derjaguin, B. V. Discuss. Faraday Soc. 1966, 42, 109-119.

14. Kistenmacher, H.; Lie, G. C.; Popkie, H.; Clementi, E. J. Chem. Phys. 1974, 61, 546-561.

15. Erlander, S. R. Phys. Rev. Lett. 1969, 22, 177-179.

16. Erlander, S. R. Phys. Rev. A 1970, 1, 868-872.

17. Abraham, F. F. J. Chem. Phys. 1974, 61, 1221-1225.

18. Anick, D. J. J. Phys. Chem. 2005, 109, 5596-5601.

19. Parthasarathi, R.; Subramanian, V.; Sathyamurthy, N. J. Phys. Chem. 2005, 109, 843-850.

20. Burnham, C. J.; Petersen, M. K.; Day, T. J. F.; Iyengar, S. S.; Voth, G. A. J. Chem. Phys. 2006, 124, 024327/1-024327/9; Burnham, C. J.; Reiter, G. F.; Mayers, J.; Abdul-Redah, T.; Reichert, H.; Dosch, H. Phys. Chem. Chem. Phys. 2006, 8, 3966-3977; de Souza, N. R.; Kolesnikov, A. I.; Burnham, C. J.; Loong, C.-K. J. Phys.: Condens. Matter 2006, 18, S2321-S2334.

21. Ohba, T.; Kanoh, H.; Kaneko, K. Chem.-Eur. J. 2005, 11, 4890-4894.

22. Ma, B. Q.; Sun, H. L.; Gao, S. Chem. Commun. 2005, 23362338.

23. Wei, M.; He, C.; Hua, W.; Duan, C.; Li, S.; Meng, Q. J. Am. Chem. Soc. 2006, 128, 13318-13319.

24. Ghosh, S. K.; Bharadwaj, P. K. Inorg. Chem. 2004, 43, 68876889.

25. Alpoguz, H. K.; Kaya, A.; Memon, S.; Yilmaz, M. J. Macromol. Sci., Part A: Pure Appl. Chem. 2007, 44, 1720; Seganish, J. L.; Santacroce, P. V.; Salimian, K. J.; Fettinger, J. C.; Zavalij, P.; Davis, J. T. Angew. Chem., Int. Ed. 2006, 45, 3334-3338.
26. Bergougnant, R. Ph.D. Thesis, University of Basel, 2006.

27. Cheng, L.; Lin, J. B.; Gong, J. Z.; Sun, A. P.; Ye, B. H.; Chen, X. M. Crystal Growth Design 2006, 6, 2739-2746.

28. Maheshwary, S.; Patel, N.; Sathayamurthy, N.; Kulkarny, A. D.; Gadre, S. R. J. Phys. Chem. A 2001, 105, 1052510537.

29. Bergougnant, R. D.; Robin, A. Y.; Fromm, K. M. Crystal Growth Design 2005, 5, 1691-1694.

30. Ermer, O.; Neudörfl, J. Chem.-Eur. J. 2001, 7, 4961-4980.

31. Yoshizawa, M.; Kusukawa, T.; Kawano, M.; Ohhara, T.; Tanaka, I.; Kurihara, K.; Niimura, N.; Fujita, M. J. Am. Chem. Soc. 2005, 127, 2798-2799.

32. Buck, U.; Huisken, F. Chem. Rev. 2000, 100, 3863-3890.

33. Clague, N. P.; Clegg, W.; Coles, S. J.; Crane, J. D.; Moreton, D. J.; Sinn, E.; Teat, S. J.; Young, N. A. Chem. Commun. 1999, 379-380.

34. Kondo, Y.; Endo, K.; Hamada, F. Chem. Commun. 2005, 711-712.

35. Fages, F.; Desvergne, J. P.; Bouas-Laurent, H. J. Org. Chem. 1994, 59, 5264-5271.

36. Clegg, W.; Drummond, A. M.; Mulvey, R. E.; O’Shaughnessy, P. Chem. Commun. 1997, 1301-1302.

37. Bakker, W. I. I.; Haas, M.; Khoo-Beattie, C.; Ostaszewski, R.; Franken, S. M.; de Hertog, H. J.; Verboom, W.; de Zeeuw, D.; Harkema, S.; Reinhoudt, D. J. Am. Chem. Soc. 1994, 116, 123-133.

38. Whang, D.; Heo, J.; Park, J. H.; Kim, K. Angew. Chem., Int. Ed. 1998, 37, 78-80.

39. Buschmann, H. J.; Wenz, G.; Cleve, E.; Schollmeyer, E. Acta Chim. Slov. 2000, 47, 55-61.

40. Cosier, J.; Glazer, A. M. J. Appl. Crystallogr. 1986, 19, 105107.

41. Blanc, E.; Schwarzenbach, D.; Flack, H. D. J. Appl. Crystallogr. 1991, 24, 1035-1041.

42. Sheldrick, G. M. SHELX-99, Program for Crystal Structure Refinement; University of Göttingen: Göttingen, 1999. 